\title{
A Washback Study on the Similarities and Differences Between CET4 and CET6 from Students' Perspective*
}

\author{
Peirong Yang \\ School of Foreign Studies \\ Anhui Sanlian University \\ Hefei, China
}

\begin{abstract}
By using questionnaire and interview, this paper mainly studies the similarities and differences of the washback between CET4 and CET6 on students' English learning. The results show that: students claim there are both similarities and differences of the washback of CET4 and CET6 on their learning. The similarities show CET4 and CET6 both have washback, and the positive washback is stronger than the negative one. The differences show the washback of CET4 is much stronger than of CET6.
\end{abstract}

Keywords-CET4 and CET6; washback; similarities and differences

\section{INTRODUCTION}

Alderson \& Wall (1993) pointed out that in the field of language education, any exam will have more or less influence on teaching, that is, the washback of the exam. In order to improve teaching quality, teachers should study the washback of the exam [1]. CET is a national teaching examination presided over by the Higher Education Department of the Ministry of Education. The purpose is to promote the implementation of the "Course Requirements for College English Teaching," and to provide an objective and accurate measure of the English ability of college students, in order to improve the teaching quality of Chinese College English courses. At present, the research on the washback of CET is mostly limited to CET4, seldom relates to CET6, and there are few comparative studies on the similarities and differences between CET4 and CET6 washback. And He Chunxiu (2017) suggested in his study of washback that it is possible to explore the washback from the perspective of the learner on the test [2]. In view of this, this article intends to explore the similarities and differences between the CET4 and CET6 washback from the perspective of students. It is of great significance to study the washback of CET from the perspective of students because students are direct participants and affected persons of CET.

\section{RESEARCH DESIGN}

The questionnaire designed in this study is based on the

*Fund Project: Anhui University Humanities and Social Sciences Research Project: "An Empirical Study on the Washback of TEM4" (Project No.: SK2018A0673) assumption of the washback hypothesis of Alderson \& Wall (1993) [1] summarized by Qi Luxia (2004) [3]. It also draws on the survey questionnaire of Gu Xiangdong (2007) [4]. The questionnaire mainly involved students' understanding of CET4 and CET6 and their attitudes, the overall impact of CET4 and CET6 on students' English learning, and their influence in various aspects.

The subject of this study involves 240 undergraduate students who have participated in CET4 and CET6 in four universities in a certain area. Because it is a comparative study, each student needs to complete two questionnaires about CET4 and CET6 washback. The recovery rate for both questionnaires was $97.9 \%$. The researchers used SPSS20.0 to analyze the questionnaire data, mainly using the analysis results of the paired sample T-test to explore whether the washback of CET4 and CET6 was significantly different. For those in doubt, the investigators selectively interviewed some of the students in order to further explore the similarities and differences between CET4 and CET6 in the washback of students' English learning.

\section{RESULTS AND DISCUSSION}

This section mainly studying the similarities and differences of the washback of the two Tests on students' English learning by comparing the students' understanding degree and the attitude of CET4 and CET6 with their attitudes, the overall impact of CET4 and CET6 on students' English learning, and the impact of various aspects, and the emphasis placed by students and their institutions on CET4 and CET6.

\section{A. Students' Understanding Degree of CET4 and CET6}

Bailey (1996) [5] once pointed out that students' understanding of a test and its purpose can increase the positive washback of the test to a certain extent. Based on this, the researchers first analyzed students' understanding of CET4 and CET6 in order to explore the similarities and differences between the two washback.

Students are direct participants in CET. How do they understand CET4 and CET6? What are the similarities and differences? From the data in Table $1,44.0 \%$ of the students are very familiar with or understand CET4. $22.3 \%$ of the 
students know or understand CET6 well. The proportion of students who do not know or do not understand CET6 is greater than that of CET4. According to interviews, the reason why students know more about CET4 is that students can apply for CET6 only if their CET4 score reaches a certain level. In addition, the Mean values in Table 1 show that students have a general understanding of CET4 and do not know much about CET6. Students' understanding of these two types of examinations is not very satisfactory. According to Bailey (1996) [5], this may not be conducive to the emergence of CET4 and CET6 positive washback. In addition, the paired sample T-test had a Sig value of .000, indicating that there was a significant difference in the students' understanding of CET4 and CET6. This may be one of the reasons for the difference in the washback of these two tests on students' English learning.

TABLE I. STUDENTS' UNDERSTANDING DEGREE OF CET4 AND CET6

\begin{tabular}{ccccccccc}
\hline $\begin{array}{c}\text { Band } \\
\text { s }\end{array}$ & $\mathbf{N}$ & $\begin{array}{c}\mathbf{5 + 4} \\
(\boldsymbol{\%})\end{array}$ & $\begin{array}{c}\mathbf{3} \\
(\boldsymbol{\%})\end{array}$ & $\begin{array}{c}\mathbf{2 + 1} \\
(\boldsymbol{\%})\end{array}$ & $\begin{array}{c}\text { Mea } \\
\mathbf{n}\end{array}$ & $\mathbf{S D}$ & $\mathbf{r}$ & \multirow{2}{*}{ Sig } \\
\hline CET4 & 196 & 44.0 & 26.8 & 29.2 & 3.22 & 1.077 & $.508 * * *$ & .000 \\
CET6 & 196 & 22.3 & 33.5 & 44.1 & 2.73 & .946 & \\
\hline
\end{tabular}

a. Note: The researchers divided the five scales into $5+4,3$, and $2+1$ types for statistical analysis. A small value of 0.05 for Sig is considered to be a significant difference.

b. (5. Very well understood 4. Relative understanding 3. Ordinary understanding 2. do not know much 1 . Do not understand at all )

\section{B. Attitudes of Students Towards CET4 and CET6}

The purpose of CET is to test students' English proficiency and improve the quality of college English teaching. So, how is the student's acceptance of CET4 and CET6? According to the analysis in Table 2, more than $54 \%$ of the students strongly agree or agree with CET4 and CET6, $36.8 \%$ of the students hold an indifferent attitude, and a few students (CET: $8.7 \%$, CET6: $12.6 \%$ ) hold negative attitude on the two examinations. The researchers interviewed students who were indifferent or negative. They said that there is little chance of engaging in English-related work in the future. Professional courses are more important than English. In this regard, the researchers suggest that teachers should correct the attitude of some students to learn English, so that "college English teaching requirements" can really be implemented.

In addition, from the Mean value, the student's attitude towards CET4 is more positive than that of CET6, and the paired sample T-test Sig value shows that the students' attitude towards CET4 and CET6 is significantly different. This is consistent with the students' understanding degree of the two examinations. This may be another reason for the difference in CET4 and CET6 washback of students' English learning. Why do students prefer CET4? From the above analysis, students learn more about CET4 than CET6. Is there relationship between the degree of understanding of an exam and the attitude of the exam? Interested researchers can conduct research on this. Because the significance of exploring this relationship lies in the fact that we can increase students' understanding of the test and increase their acceptance of the test, so as to stimulate the emergence of the test, and further improve the quality of teaching.
TABLE II. STUdENTS' ATtitudes TOWARDS CET4 AND CET6

\begin{tabular}{lcccccccc}
\hline Bands & $\mathbf{N}$ & $\begin{array}{c}\mathbf{5 + 4} \\
(\boldsymbol{\%})\end{array}$ & $\begin{array}{c}\mathbf{3} \\
(\boldsymbol{\%})\end{array}$ & $\begin{array}{c}\mathbf{2 + 1} \\
(\boldsymbol{\%})\end{array}$ & Mean & SD & r & Sig \\
\hline CET4 & 231 & 54.6 & 36.8 & 8.7 & 3.58 & .845 & .378 & .030 \\
CET6 & 231 & 50.7 & 36.8 & 12.6 & 3.44 & .882 & $* * *$ & .030 \\
\hline \multicolumn{1}{c}{ a. } & (5. Strongly Agree 4. Relatively agree 3. indifferent 2. do not agree much $\begin{array}{c}\text { 1. Strongly } \\
\text { oppose) }\end{array}$
\end{tabular}

\section{The Overall Impact of CET4 and CET6 on Students'} English Learning and Their Impact on All Aspects

This section mainly explores students' perceptions of the overall impact of CET4 and CET6 on their English learning and the impact of various aspects in order to positively understand the washback of these two tests. From Table 3, $45.2 \%$ of students believe that CET4 has a very positive or positive impact on their English learning. For CET6, the ratio is $39.4 \%$. In addition, some students believe that the two examinations have no influence on their English learning, and the proportion is even greater than the proportion that believes that there are positive effects and positive effects (CET4: $45.7 \%$, CET6:48.1\%). This is consistent with the assumption of the washback of Alderson \& Wall (1993)[1] that "an exam affects some students and has no effect on some students". There are also a small number of students who believe that CET4 and CET6 have a negative impact on their English learning (CET4: 9.1\%; CET6: 12.6\%). From Mean's value, students generally believe that CET4 and CET6 have an influence on their English learning, and the positive influence is greater than the negative effect. Moreover, students think that CET4 has greater influence on their English learning than CET6. Although students have different attitudes towards the impact of CET4 and CET6 on their English learning, the paired sample T-test results show that there is no significant difference in the total impact of these two tests on students' English learning.

TABLE III. THE TOTAL IMPACT OF CET4 AND CET6 ON STUDENTS' ENGLISH LEARNING

\begin{tabular}{|c|c|c|c|c|c|c|c|c|}
\hline Bands & $\mathbf{N}$ & $\begin{array}{l}5+4 \\
(\%)\end{array}$ & $\begin{array}{c}3 \\
(\%)\end{array}$ & $\begin{array}{l}2+1 \\
(\%)\end{array}$ & Mean & SD & $\mathbf{r}$ & Sig \\
\hline CET4 & 230 & 45.2 & 45.7 & 9.1 & 3.72 & .759 & \multirow{2}{*}{$\begin{array}{l}.438 \\
* * *\end{array}$} & \multirow{2}{*}{.058} \\
\hline CET6 & 230 & 39.4 & 48.1 & 12.6 & 3.52 & .803 & & \\
\hline
\end{tabular}

Since students generally believe that CET4 and CET6 have an impact on their English learning, and the positive impact is greater than the negative impact, and CET4 has a greater impact on their English learning than CET6. So, will these two tests have any impact on students' English learning in all aspects? What is the effect? What are the differences and similarities? This is the next question to be explored. In this article, all aspects of English learning refer to learning objectives, learning attitudes, learning content, and learning methods.

From "Table IV", we can see that in terms of the impact of CET4 and CET6 on students' English learning in all aspects, more than $40 \%$ of students think the impact is very positive or positive, and more than one third think that there is no impact, and a few students believe that it has a negative influence or 
influence is very negative. Students believe that CET4 and CET6 have an impact on all aspects of their English learning, and the positive impact is greater than the negative impact. This verifies the washback hypothesis of Alderson \& Wall (1993)[1]: "An exam may affect what students learn, how they learn, the degree and depth of learning, and the effects of learning."

According to Mean's value, in addition to the "learning method" and "study progress", students think that CET6 has greater influence on their English learning than CET4. However, the T-test value of the paired sample showed that there was no significant difference in the impact of CET4 and CET6 on students' English learning. We know that students' learning methods and learning progress have little to do with CET4 or CET6. In addition to these two points, students think that the reason CET6 has a greater impact on their other learning aspects is that students think that CET6 is more difficult showed by the interviews. In order to pass the exam, students' learning attitude, learning depth, and breadth of learning are all more advanced than when preparing CET4. From this point of view, it seems to students that difficult exams have a greater impact on all aspects of their English learning.

TABLE IV. IMPACT OF CET4 AND CET6 ON STUDENTS' VARIOUS ASPECTS OF ENGLISH LEARNING

\begin{tabular}{|c|c|c|c|c|c|c|c|c|c|}
\hline & Bands & $\mathbf{N}$ & $5+4(\%)$ & $3(\%)$ & $2+1(\%)$ & Mean & SD & $\mathbf{r}$ & Sig \\
\hline \multirow{2}{*}{$\begin{array}{l}\text { Learning } \\
\text { target }\end{array}$} & CET4 & 227 & 53.2 & 39.7 & 7.0 & 3.55 & .804 & $.409 *$ & \multirow{2}{*}{.326} \\
\hline & CET6 & 227 & 55.3 & 36.0 & 8.7 & 3.61 & .921 & $* *$ & \\
\hline \multirow{2}{*}{$\begin{array}{l}\text { Learning } \\
\text { attitude }\end{array}$} & CET4 & 227 & 52.9 & 38.4 & 8.7 & 3.53 & .832 & $.476^{*}$ & \multirow{2}{*}{.260} \\
\hline & CET6 & 227 & 58.4 & 31.6 & 10.1 & 3.60 & .889 & $* *$ & \\
\hline \multirow{2}{*}{$\begin{array}{l}\text { Learning } \\
\text { content }\end{array}$} & CET4 & 229 & 50.8 & 38.3 & 10.9 & 3.48 & .841 & $.372 *$ & \multirow{2}{*}{.342} \\
\hline & CET6 & 229 & 55.2 & 34.8 & 10.0 & 3.54 & .891 & $* *$ & \\
\hline \multirow{2}{*}{$\begin{array}{l}\text { Learning } \\
\text { methods }\end{array}$} & CET4 & 229 & 49.6 & 41.3 & 9.2 & 3.49 & .820 & $.392 *$ & \multirow{2}{*}{.481} \\
\hline & CET6 & 229 & 49.1 & 40.0 & 10.8 & 3.45 & .875 & $* *$ & \\
\hline \multirow{2}{*}{$\begin{array}{l}\text { Learning } \\
\text { depth }\end{array}$} & CET4 & 227 & 51.8 & 39.5 & 8.8 & 3.48 & .817 & $.471 *$ & \multirow{2}{*}{.467} \\
\hline & CET6 & 227 & 53.3 & 34.9 & 11.8 & 3.53 & .942 & $* *$ & \\
\hline \multirow{2}{*}{$\begin{array}{l}\text { Learning } \\
\text { width }\end{array}$} & CET4 & 226 & 46.1 & 41.7 & 12.2 & 3.38 & .852 & $.431 *$ & \multirow{2}{*}{.078} \\
\hline & CET6 & 226 & 54.0 & 34.2 & 11.9 & 3.49 & .905 & $* *$ & \\
\hline \multirow{2}{*}{$\begin{array}{l}\text { Learning } \\
\text { progress }\end{array}$} & CET4 & 227 & 45.9 & 39.7 & 14.4 & 3.37 & .848 & $.555^{*}$ & \multirow{2}{*}{.072} \\
\hline & CET6 & 227 & 43.7 & 37.0 & 19.2 & 3.26 & .932 & $* *$ & \\
\hline \multirow{2}{*}{$\begin{array}{l}\text { Learning } \\
\text { effect }\end{array}$} & CET4 & 228 & 41.5 & 39.7 & 18.8 & 3.25 & .907 & $.440 *$ & \multirow{2}{*}{.840} \\
\hline & CET6 & 228 & 42.2 & 36.1 & 21.7 & 3.26 & .948 & $* *$ & \\
\hline
\end{tabular}

(5. Very positive 4 . Relative positive 3 . No influence 2 . Relative negative 1 . Very negative)

Overall, from this part of the analysis, students generally believe that CET4 and CET6 have an impact on their English learning, and the positive impact is greater than the negative impact. In addition, students believe that the total impact of CET4 on their English learning is greater than that of CET6, but CET6 has greater influence on all aspects of their English learning than CET4. Although the overall impact of CET4 and CET6 on students' English and the impact of various aspects are different, the difference is not obvious.

\section{The Degree to Which Students and Their Institutions Attach Importance to CET4 and CET6}

As we all know, the purpose of CET is to test students' ability to use English comprehensively, and to promote the implementation of the "Course Requirements for College English Teaching." Since CET has such an important role in college English teaching, what is the degree of emphasis that students and their institutions place on the exam? What is the difference between CET4 and CET6? This is the issue to be studied in this section.

From "Table V", it is clear that more than $70 \%$ of students attach great importance to or pay more attention to CET4 and CET6. More than $20 \%$ of students attach importance to these two examinations. A few students think that CET4 and CET6 are not important. Mean shows that, in general, students think that both exams are important. CET4 is more important than CET6. The Sig value shows that students have significant differences in the importance of CET4 and CET6.

Why do students think that CET4 is more important than CET6? According to the previous analysis, students have better understanding and support of CET4 than CET6. It can be said that there is actually a positive correlation between the three. From the interviews, the students believe that the first test of CET4 and the application for CET6 is based on the fact that CET4 reaches a certain number of points, so they think that CET4 is more important than CET6.

TABLE V. STUdent's EMPHASIS DEgREE ON CET4 AND CET6

\begin{tabular}{|c|c|c|c|c|c|c|c|c|}
\hline Bands & $\mathbf{N}$ & $\begin{array}{l}5+4 \\
(\%) \\
\end{array}$ & $\begin{array}{c}3 \\
(\%) \\
\end{array}$ & $\begin{array}{l}2+1 \\
(\%) \\
\end{array}$ & Mean & SD & $\mathbf{r}$ & Sig \\
\hline CET4 & 230 & 72.3 & 25.1 & 2.6 & 4.03 & .891 & .235 & .01 \\
\hline CET6 & 230 & 70.0 & 23.5 & 6.5 & 3.85 & .876 & $* * *$ & 4 \\
\hline
\end{tabular}

Due to the limitations of the study, the researchers only explored the students' mouths of academic focus on CET4 and 
CET6. From Table 6, it can be seen that more than $60 \%$ of students think that their institutions attach great importance to or pay more attention to these two kinds of examinations. 1/5 students think that their institutions are of the same degree of importance, and a small number of students consider that their institutions do not pay attention to these two tests. According to Mean's value, in terms of students, their institutes pay more attention to CET4 and CET6. Compared with CET6, they pay more attention to CET4, and the Sig value shows that there is a significant difference between the two.

TABLE VI. Their COlleges' EMPhasis Degree on CET4 ANd CET6

\begin{tabular}{|c|c|c|c|c|c|c|c|c|}
\hline Bands & $\mathrm{N}$ & $\begin{array}{l}5+4 \\
(\%)\end{array}$ & $\begin{array}{l}3 \\
(\%)\end{array}$ & $\begin{array}{l}2+1 \\
(\%)\end{array}$ & Mean & SD & $r$ & Sig \\
\hline CET4 & 228 & 76.3 & 20.6 & 3.1 & 4.09 & .858 & .274 & \multirow{2}{*}{.000} \\
\hline CET6 & 228 & 62.3 & 29.0 & 8.7 & 3.75 & .901 & $* * *$ & \\
\hline
\end{tabular}

In general, students and their institutions attach great importance to CET4 and CET6, but as Sig can see, there is a significant difference in the degree of emphasis placed on CET4 and CET6 by students and their institutions. In comparison, CET4 is more valued. The fact that CET4 is more important also explains why the students discussed above understand and support CET4 more, and that CET4 has a greater impact on their English learning than CET6.

\section{CONCLUSION}

This article compares the differences and similarities between CET4 and CET6 of washback of students' English learning mainly with questionnaires and interviews. The research starts from the aspect and the positive. The aspect study mainly starts from the students' understanding degree of the two examinations and their attitudes, the importance degree students and their institutions attach to the examination. Positive studies mainly include students who believe that CET4 and CET6 can help them learn English. The total impact and various aspects of the impact are in two aspects. Positive research mainly includes students' belief that CET4 and CET6 have the various impact and the total impact influences on their English learning. "Similarities" is mainly reflected in the fact that both tests have had an impact on their English learning, and the positive impact is far greater than the negative impact. The "difference" is mainly reflected in the impact of CET 4 is far greater than CET6.

Studies have shown that some students do not know much about CET4 and CET6 and have an unsupportive attitude. Language testing should serve language teaching (Yang Huizhong, 1999) [6]. In order to better promote the active washback of CET4 and CET6, teachers should promote CET4 and CET6 through multiple channels and multiple means, and ensure that students better understand the purpose of the test, the nature of the test, etc., and correct students' attitude to the test. Thereby promote the active washback of the test, make it better for language teaching services.

\section{REFERENCES}

[1] Alderson J.C., \& Wall, D. Does Washback Exist?[J]. Applied Linguistics. 1993(2), 115-129.

[2] He Chunxiu. The washback of school exam policies on foreign language learners: A survey based on college English exams [J] Foreign Language Testing and Teaching. 2017(4):46-51. 何春秀. 学校 考试政策对外语学习者的反拨效应: 基于大学英语考试的一项调查 [J]. 外语测试与教学. 2017(4):46-51.

[3] Qi L. X.. The intended washback effect of the national matriculation English test in China: intentions and reality[M]. Beijing: Foreign Language Teaching and Research Press, 2004.

[4] Gu, X. D. Positive or negative?-An empirical study of CET washback[M]. Chongqing: Chongqing University Press, 2007.

[5] Bailey, K. M. Working for washback: a review of the washback concept in language testing[J]. Language Testing. 1996(3): 257-279.

[6] Yang Huizhong. Language Testing and Language Teaching [J]. Foreign Languages. 1999(1): 39-44. 杨惠中. 语言测试与语言教学[J]. 外语界. 1999(1): 39-44. 